\title{
The ministry of women among early Calvinistic Baptists
}

\section{lan Birch}

Scottish Baptist College, University of the West of Scotland, Paisley, UK lan.Birch@uws.ac.uk

\begin{abstract}
Although there is considerable documentation of women preachers during the English Civil War period and the Interregnum, it is clear that such activities were not encouraged among English Calvinistic Baptists, and most especially among Particular Baptists. Yet there was a tension in even the most restrictive Baptist teaching on this subject. For since Baptists had opened the door to congregational participation in the public ministry of the church, they were faced with the problem of partially closing that door in order to restrict the ministry of women to that of diakonia, and good works. Nevertheless, a small number of women have been identified as both prophets and Particular Baptists, and the nature and context of their ministry illustrates the role of women in early Baptist communities.
\end{abstract}

Keywords: Baptists, English Civil War, Interregnum, prophecy, women preachers

Throughout the Civil War period, and Interregnum, the activities of women preachers were documented in a number of publications ${ }^{1}$ showing that the prophetic activity of Puritan and sectarian women was gaining notoriety. ${ }^{2}$ Among English Calvinistic Baptists, however, the preaching ministry of women was not encouraged. J. F. McGregor judges that 'Baptists were the most conservative of the radical Puritan movements in their attitudes

${ }^{1}$ E.g. A Discovery of Six Women-Preachers in Middlesex, Kent, Cambridge, and Salisbury. with a Relation of Their Names, Manners, Life, and Doctrine (London, 1641); Thomas Edwards, Gangraena, or, A catalogue and discovery of many of the Errors, Heresies, Blasphemies and pernicious Practices of the Sectaries of this time, vented and acted in England in these four last years (London, 1646). Ethyn Morgan Williams regarded women preachers in the Civil War period as an early manifestation of feminism rooted in freedom of expression and radical individualism. There is little evidence of this motivation in these women's writings, the greater impetus being theological, namely that God had given his Spirit equally to women as men enabling both to prophesy. See E. M. Williams, 'Women Preachers in the Civil War', Journal of Modern History 1/4 (1929), pp. 561, 569.

2 See Claire Cross, "“He-Goats Before the Flocks": A Note on the Part Played by Women in the Founding of Some Civil War Churches', Studies in Church History 8 (1972), pp. 195-202. Cross recounts the exploits of Dorothy Hazard in the Broadmead church in Bristol. 
to women', 3 and the majority of their public statements were certainly restrictive. In this matter Particular Baptists were hardly more conservative than other mainstream Puritans, and the Independent Thomas Goodwin was equally certain 'that women should not speak in public, but be silent, it is the law of nature'. ${ }^{4}$ It is true, however, that Particular Baptists were more conservative than General Baptists who showed more tolerance of women speaking in church gatherings, the most notorious of whom was Mrs Attaway of Thomas Lamb's Bell-Alley church. ${ }^{5}$

At a sociological level, the dominant patriarchal structure of the period served to suppress the ministry of women in churches. ${ }^{6}$ This is evidenced by the petition of the Lord Mayor and some Aldermen, and the CommonCouncil of London, to the House of Commons in January 1645/6, calling for the speedy settlement of church government on account of 'some Instances of private Meetings of Women Preachers, of new and strange Doctrines and Blasphemies that are vented'?

The Particular Baptist ideological commitment to primitivism, however, meant that Apostolic ordinances took precedence over all other ideological considerations. The first statement issued by Particular Baptists dealing precisely with this question is in the Association Records of the West Country in 1653. The messengers discussed the question, 'Whether a woman may speak in the church at all, and if at all, in what cases?' The answer, which was intended to serve as a guideline for the churches, stated:

3 This was especially true when compared to the Levellers and Quakers. J. F. McGregor, 'The Baptists: Fount of All Heresy', in J. F. McGregor and B. Reay (eds), Radical Religion in the English Revolution (Oxford: OUP, 1984), p. 47.

4 Thomas Goodwin, The Works of Thomas Goodwin, vol. 9 (Edinburgh: James Nichol, 1864), $\mathrm{XI}, 11$. The Independent John Rodgers was marginally more generous to women in his Dublin congregation, allowing them to speak and vote, when it was in subjection to the church, but not to teach or rule. See John Rodgers, Ohel or Beth-Shemesh (London, 1653), p. 294.

${ }^{5}$ See Thomas Edwards, Gangraena, i.ii.29, 31, 32; ii.9. On Edwards, see Ann Hughes, Gangraena and the Struggle for the English Revolution (Oxford: OUP, 2004), pp. 112-15. On Mrs Attaway see Curtis Freeman, 'Visionary Women among Early Baptists', Baptist Quarterly 43/5 (Jan. 2010), pp. 260-83. On the ministry roles of women among the early General Baptists see John Briggs, 'She-Preachers, Widows and Other Women: The Feminine Dimension in Baptist Life since 1600', Baptist Quarterly 31/7 (1986), pp. 337-52.

6 Diane Willen, 'Godly Women in Early Modern England: Puritanism and Gender', Journal of Ecclesiastical History 43/4 (Oct. 1992), p. 566.

7 'House of Commons Journal Volume 4: 15 January 1646', Journal of the House of Commons: volume 4: 1644-1646 (1802): 407-8. http://www.british-history.ac.uk/report.aspx? compid=23595; accessed Jan. 2013. 
a woman is not permitted to speak at all in the church, neither by way of praying, prophecying nor enquiring, 1 Cor 14.34f, 1 Tim. 2.11f, but, if any have a gift, we judge they may exercise it in private, observing the rule mentioned, 1 Cor. $11.5 .^{8}$

This statement was almost certainly formulated by Thomas Collier, who elsewhere in writing showed himself implacably opposed to women ministering publicly by word, whether it be called 'prophesying', 'preaching', 'teaching' or 'exercising' . In The Right Constitution and True Subjects of the Visible Church of Christ, where he is dealing with orderly speaking in church worship he writes:

that there be no disorder in speaking, for in the managing of the affairs of Gods house there is permission but for one at a time to speak upon any account, what is more will be confusion, 1 Cor 14.31, 33. and women are not permitted to speak in the Church, 1 Cor. $14.34 .^{10}$

In the chapter, 'Of the Ministry of Christ in his Church in way of Prophecie', Collier affirmed that the prophetic gift ought to be exercised in the church, for the building up of the church. To whom does the gift of prophecy pertain? He affirms his former position: 'to all that have the gift, except Women, they are commanded to be in silence, 1 Cor 14,34 '. ${ }^{11}$ The one exception to this position occurs in Collier's letter to Thomas Hall of Kings Newton, who had attacked the unauthorised ministry of the Particular Baptists. In a passage where Collier is trying to justify lay preaching, on the basis of 1 Cor 14:31, he argues that, since the Apostle commands all that have gifts should use them, including the gift of prophecy, the ministry of proclamation in the congregation is according to Gift and not Office, and any Saint, so moved by the Spirit might prophesy. Hall responded that this must be an erroneous interpretation of the scripture, since if all the saints were included in this saying women also would be permitted to prophesy. Collier replied:

The Scripture it self is clear, women are excepted, ver.34. All may, \&c, There is no limitation, no prohibition of any; except women; and women are

8 B. R. White (ed.), Association Records of the Particular Baptists of England, Wales, and Ireland to 1660 (hereafter ARPB) (Didcot: Baptist Historical Society, 1971-4), p. 55.

9 On the distinction between terms see Phyllis Mack, Visionary Women: Ecstatic Prophecy in Seventeenth Century England (Berkeley, CA: University of California Press, 1992), p. 107.

10 Thomas Collier, The Right Constitution and True Subjects of the Visible Church of Christ (London: Henry Hills, 1654), p. 26 (original italics).

11 Ibid., pp. 34-5. 
not altogether forbidden neither; compare this with cha. 11.5. Joel 2.28. women may Prophesy by permission, and in subjection to the man, \&c. ${ }^{12}$

The equivocation in Collier's statement about women speaking highlights an inconsistency in early Baptist theology of ministry. Necessity being the mother of invention, and Baptists lacking educated and ordained ministry in many of their churches, the obvious recourse was to the theology and practice of the ministry of all believers. Having opened the door to congregational participation in the ministry of the church, they were now faced with the problem of partially closing the door in order to restrict the ministry of women to that of diakonia, and good works. While Collier admitted to Thomas Hall that women were potentially gifted by the Spirit to prophesy, this, he argues, was only hypothetical, because in practice they would not be permitted to speak on the basis of 1 Corinthians 14:34. This was undoubtedly Collier's deepest conviction on the subject.

At a General Meeting of the Abingdon Association of Baptists at Tetsworth on 30 March 1658 the matter was discussed, 'How far women may speake in the church and how far not?' The answer was consistent with the policy of Collier, but more nuanced and comprehensive for which reason it is cited in full:

Answer. We answere: that women in some cases may speake in the church and in some cases againe may not.

1. That in some cases they may not speake manifestly appeares in 1 Cor. 14.34f. and 1 Tim 2.11f. They may not so speake as that their speaking shall shew a not acknowledging of the inferioritie of their sexe and so be an usurping authoritie over the man, more particularly,

i. A woman may not publikely teach in the church. This appears to have bene much in the apostle's eye in 1 Cor. 14 .

ii. She may not stand up as a ruler in the church and so speake upon that account.

iii. She may not speake in the church by way of passing sentence upon doctrines or cases in the church.

iv. She may not speake in prayer as the mouth of the church. This is verie cleare in $1 \mathrm{Tim} .2$.

2. Yet in the cases that follow and possibly in some other like cases a woman may speake in the church and not be found to offend against the rules of the apostle.

12 Thomas Collier, The Pulpit-Guard Routed, in Its Twenty Strong-Holds (London: Giles Calvert, 1651), p. 79. 
i. If she desire to make confession of her faith and to expresse her desire of baptisme and communion with the church.

ii. If she be a witnesse concerning the admonition of one that the church is to deale with or must herself tell a matter to the church according to the rule in Mat. 18.17.

iii. If a woman hath sinned and be cast out of the church and God hath given her repentance undoubtedly she may manifest it in the church.

To these cases the messengers now mett at Tetsworth added as followeth:

Query. Whether when a person propounds to a church for communion and some sister knowes something concerning this person which she judgeth doth render this person unfit for the same and which she conceives the church is ignorant of, it be not her libertie to signify to the church [by] her owne mouth her not being satisfied.

[Answer. We]e judge it is her libertie. ${ }^{13}$

On the basis of elements in this statement it could be argued that early Baptists believed in the spiritual equality of the sexes. Being committed to the principle of a believer's church, it was required of women, in the same manner as men, to give personal testimony to the experimental work of regeneration. ${ }^{14}$ Likewise, it was necessary for a woman to request her own baptism since not even a husband could stand proxy for a woman's conscience. ${ }^{15}$ The work of grace in a woman's soul was considered to be identical to that in the soul of a man. ${ }^{16}$ They might also give evidence in cases

13 ARPB, p. 185 (formatting as original).

14 Two Independent ministers, John Rogers and Henry Walker, published collections of testimonies given by postulants for admission to their congregations, amongst which are a considerable number of women's testimonies, showing that this was a common feature of sectarian religion. See Michael Watts, The Dissenters, vol. 1 (Oxford: Clarendon Press, 1978), pp. 174-5; also, Anne Laurence, 'A Priesthood of She-Believers: Women and Congregations in Mid-Seventeenth-Century England', Studies in Church History 27 (1990), p. 348.

15 On this point see the case of Jane Adams, who was censured by the Fenstanton church for absenting herself from meetings because 'her husband would not suffer her'. The church decreed that in such cases a husband had no power over the conscience of his wife. E. B. Underhill (ed.), Records of the Churches of Christ (London: Haddon Brothers \& Co., 1854), p. 242.

16 See Keith Thomas, 'Women and the Civil War Sects', in Trevor Aston (ed.), Crisis in Europe 1560-1660 (London: Routledge \& Kegan Paul, 1965), p. 320. 
of discipline, ${ }^{17}$ and make repentance of $\sin$. Women could also contribute to the communal discernment regarding an application for church membership. If regeneration, and a direct relationship with God could be fully and equally experienced by both sexes, it is all the more striking that in regard to the outworking of grace in the fruits of a speaking ministry, women were not regarded as equal to their male counterparts.

Two reasons against the preaching ministry of women are prominent in this resolution. First, a hermeneutical commitment to biblical literalism meant the Pauline injunction against women speaking in 1 Corinthians 14 was decisive. The addition of 1 Timothy 2:11-12, prohibiting women from teaching, appeared to Baptists incontrovertible. Secondly, this hermeneutical decision reflected an a priori belief in the 'inferioritie of their sexe', ${ }^{18}$ or as some male counterparts defined, 'the weaker vessel', ${ }^{19}$ a concept about gender that was sociologically normative for the time, but without apostolic warrant. ${ }^{20}$ The particular inferiority and weakness with which women were

17 Evidence of women defending themselves in disciplinary hearings among the General Baptists is found in the Fenstanton records of 1652-1653. Testimony was given by Elizabeth Browne, widow Sanders, Anne Marriat, Anne Pharepoint, widows Binns, Peppers, Sneesby, and Wiggs on charges relating to absence from worship, unequal marriage, parish church attendance and backsliding. In E.B. Underhill, Records of the Churches of Christ, Gathered at Fenstanton, Warboys, and Hexham, pp. 20-58. See also Freeman, 'Visionary Women among Early Baptists', p. 268.

18 John Bunyan held the view that women 'are not the image and glory of God as the men are', and that if a woman 'worships in assemblies, her part is to hold her tongue, to learn in silence'. When a group of women in Bunyan's church in the 1680 s sought permission to pray independently the Pastor replied: 'you should be content to wear this . . . badge of your inferiority, since the cause thereof arose at first from yourselves. 'Twas the Woman that at first the Serpent made use of . . . Wherefore the Woman, to the Worlds end, must wear tokens of her Underlyingship in all Matters of Worship'. John Bunyan, A case of Conscience Resolved (London: Benjamin Alsop, 1683), pp. 38 and 34. Phyllis Mack argues the popularity of the early Quakers, which was also the source of their threat, was that their radical and democratic principles overcame the usual gender boundaries. See Phyllis Mack, Visionary Women (Berkeley, CA: University of California Press, 1992), pp. 9-10. See also Thomas, 'Women and the Civil War Sects', p. 318.

19 Curtis Freeman (ed.), A Company of Women Preachers: Baptist Prophetesses in Seventeenth Century England (Waco, TX: Baylor University Press, 2011), p. xiii. At the impolite extremity of male opinion about women prophets was the invective penned by Mr Brookes to Lady Eleanor Davies: 'I will spend no more term time upon thee Hecate, Medusa, legion, clovenfooted Gorgon. Yet if I meet thee . . . assure thyself, I will kick thee and scratch a minced pie for a dog from thy ill kept filthy dunghill arse.' Cited in Mack, Visionary Women, p. 17.

20 In 1655 two Quaker women, Pricilla Cotton and Mary Cole were imprisoned in Exeter for preaching. Their arrest was based on a supposed violation of the biblical injunction in this text, 1 Cor 14:34. See Freeman, 'Visionary Women among Early 
supposed to be afflicted was the power of the mind. This prejudice is highlighted by the Baptist prophetess Anne Wentworth who protested:

I am reproached as a ... mad, melancholy, crackbrained, self willed, conceited Fool, and black Sinner, led by whimsies, notions, and knifknafs of my own head; one that speaks blasphemy, not fit to take the Name of God in her mouth. ${ }^{21}$

The major obstacle to the preaching ministry of women among early Particular Baptists was the hierarchical arrangement of society at large. The dominance of parents over children, masters over servants, rulers over the ruled, male over female were considered a matter of divine ordinance. The Presbyterian, Thomas Edwards, a staunch defender of social hierarchy, grouped together such phenomena as: 'Error, Schism, contempt of the Ministery, Dispising of Dominion, and speaking evil of Dignities', together with women preachers. ${ }^{22}$ Keith Thomas observes 'orthodox arguments and texts for woman's exclusion from church office had been identical with those for her subordination in general'. ${ }^{23}$ This explains why polemicists such as Edwards greatly feared the preaching of women, since he recognised that if the dam was breached in regard to the former, a flood would ensue in the latter, and traditional structures of society would be overturned. It seemed obvious that, if new social arrangements were to emerge, patriarchy would be among the casualties.

The Abingdon statement about the ministry of women was adopted by the Particular Baptists in the Midlands region and became their official policy on this issue. ${ }^{24}$ It is clear that in the provinces, from the West Country to the Midlands, the attitude of Particular Baptists towards the ministry of women in churches was extremely conservative.

Evidence that women had any ministry role in Calvinistic Baptist churches in the period of the Civil Wars and Interregnum is sparse and demonstrates

Baptists', p. 267. For a modern Baptist, and egalitarian, interpretation of the texts from 1 Corinthians, see Paul Fiddes, “'Woman's Head is Man”', Baptist Quarterly 31/8 (1986), pp. 370-83.

21 Anne Wentworth, The Revelation of Jesus Christ (London, 1679), p. 19. She was excommunicated from her church by the elders, one of whom was Hanserd Knollys. See $A$ Company of Women Preachers, p. 648.

22 Thomas Edwards, Gangraena, i.86 and iii.218. See also A Company of Women Preachers, p. 8: 'Edwards scrupulously noted the class and gender of each Baptist [indicating] that these factors, every bit as much as suitable ordination credentials, counted in disqualifying dissenting preachers who were neither university educated nor proper churchmen.'

23 Thomas, 'Women and the Civil War Sects', p. 340.

24 ARPB, p. 28. 
that female prophets associated with the Particular Baptists exercised their gifts outside the organised worship of the congregation rather than within. A small number of women have been identified as both prophets and Particular Baptists, and the nature and context of their ministry illustrates the role of women in early Baptist communities. ${ }^{25}$

Sarah Wight ${ }^{26}$ was associated with the congregation of Henry Jessey, who edited her prophetic writings. Her words were spoken from 'within the liminal space of the deathbed', 27 and made available to a wider Christian readership only via the publication of her testimony and visions under the name of Henry Jessey. Barbara Dailey locates the prophecies of Sarah Wight in the context of the ars moriendi tradition of the period and argues that this 'allowed her conversation to become an occasion for lay preaching'. ${ }^{28}$ From her bed, during seventy-six days through April to July 1647, she ministered to many who came to seek her counsel, ${ }^{29}$ offering pastoral advice, as well as biblical and doctrinal thoughts. On 24 April she spoke to a maid who was tempted to atheism and was troubled by the thought of having resisted the Spirit. ${ }^{30}$ On 9 May she gave advice to a Gentlewoman who believed 'The Devill Rules in me... I am under sin.' ${ }^{1}$ On 12 May she spoke to a woman who could not believe for salvation in Christ. ${ }^{32}$ On 24 May Sarah was questioned about her views of general redemption and free will, falling away, etc. and

25 See John Briggs, 'She-Preachers, Widows and Other Women: The Feminine Dimension in Baptist Life since 1600', Baptist Quarterly $31 / 7$ (1986), pp. 337-52; Karen E. Smith, 'Beyond Public and Private Spheres: Another Look at Women in Baptist History and Historiography', Baptist Quarterly 34/2 (1991), pp. 79-87. Freeman, 'Visionary Women among Early Baptists', pp. 260-83; A Company of Women Preachers; Laurence, 'A Priesthood of She-Believers', pp. 345-63.

26 'Wight, Sarah (b. 1631)', by Karen O'Dell Bullock in Oxford Dictionary of National Biography, online edn, ed. Lawrence Goldman (Oxford: OUP), http://www.oxforddnb.com/ view/article/69143; accessed Jan. 2013.

27 A Company of Women Preachers, 20.

28 Barbara Ritter Dailey, 'The Visitation of Sarah Wight: Holy Carnival and the Revolution of the Saints in Civil War London', Church History 55/4 (1986), p. 438.

29 The list of those who visited Sarah Wight included Baptist, Independent and Presbyterian ministers, family, friends, doctors, aristocratic women, army personnel and politicians. See Henry Jesse, Exceeding Riches of Grace Advanced by the Spirit of Grace, in an Empty Nothing Creature (London: Matthew Simmons, 1647), pp. 8-10. According to Barbara Dailey, Jessey's list of names had the effect of turning this tract into a petition for tolerance and unity in a period of political instability in the capital. 'Visitation of Sarah Wight', p. 452.

30 Jessey, Exceeding Riches of Grace Advanced, pp. 44-5.

31 Ibid., pp. 65-76.

32 Ibid., pp. 77-85. 
in response, she betrayed doctrinal beliefs closer to the General Baptists than to the Calvinistic theology of Jessey, her pastor. She stated:

The Gospel is to be held out to all the world, to the chiefest of sinners: And this is Gospel: That Christ was sent of God to them, to turn them all from their sins, and to justify and pardon them; and to give peace to them that are a far off; and that God is not willing that any should perish, but that all should repent and live. Gods willingness to reconcile the world to himself, is to be held out to all. ${ }^{33}$

On another occasion she was quizzed concerning her trinitarian orthodoxy, her response displaying considerable theological acumen. ${ }^{34}$ On 31 May, the Relator, Sarah's amanuensis, asked her whether anything had been revealed, 'how it shall goe with the Church of God?' The prophet answered, 'I know, and verily believe, it shall goe well with those that fear the Lord.'35 On 10 June, Sarah was in her weakest physical condition, seventy-five days without food, but then received a vision, or maybe a dream, since it was ten o'clock at night, and the Lord spoke to her.

Rise, and stand upon thy feet: For I have appeared to thee for this purpose, to be a Minister and a witness, both of the things thou hast seen, and in which I will appear unto thee. ${ }^{36}$

Throughout the days of her visitations Wight 'ministered' pastoral advice, dispensed biblical and theological insights, gave insight into the future fortunes of the saints. None of this took place, however, in a church, but in a bedroom. Barbara Dailey points out, 'it is Sarah Wight's illness and the threat of impending death that authenticates her public role'. ${ }^{37}$ The extremity of her circumstances, and the anticipated brevity of her life gifted Wight a public ministry in the most private of contexts. Curtis Freeman avers: "The deathbed thus transformed female speech and action, moving it from the margin to the centre of domestic and ecclesial life.'38

Elizabeth Poole was another female among the Particular Baptists who exercised a prophetic ministry beyond the bounds of the church or

33 Ibid., p. 96 (original italics).

34 Ibid., p. 120.

35 Ibid., p. 121.

36 Ibid., p. 135. Following this vision Wight broke her fast and began to regain her strength.

37 Dailey, 'Visitation of Sarah Wight', p. 444.

38 A Company of Women Preachers, p. 20. 
congregation. ${ }^{39}$ A member of William Kiffin's church from about 16 years of age, she was expelled from the congregation for heresy and immorality some time before $1648{ }^{40}$ Poole moved to Abingdon, where she came into contact with John Pendarves, minister of the Abingdon Baptist congregation, and his wife, Thomasine. Possibly through Pendarves, ${ }^{41}$ Poole came into contact with the army, which led to a brief season of prominence in national political affairs. ${ }^{42}$ In December and January 1648/9 she appeared before the General Council of the Army to offer divinely sourced wisdom concerning how the army should proceed with the King. When she first appeared on 29 December, she spoke in prophetic - and positive - terms about the role of the army in the affair. In her vision England is depicted as a sick woman, to be healed by a strong man, namely the army:

A vision was set before me, to shew her cure, and the manner of it, by this similitude: A man who is a member of the army, having sometimes much bewailed her state, saying, He could gladly be a sacrifice for her, and was set before me, presenting the body of the Army, and on the other hand, a woman crooked, sick, weak and Imperfect in body, to present unto me, the weak and imperfect state of the Kingdome: I having the gift of faith on me for her cure, was thus to appeal to the person on the other hand, That he should improve his faithfulnesse to the Kingdome, by using diligence for the cure of this woman, as I by the gift of faith on me should direct him. Neverthelesse it is not the gift of faith in me, say I, nor the act of diligence in you, but in dependence on the divine will, which cals me to believe, and you to act. ${ }^{43}$

As Marcus Nevitt pointed out, Poole's represented position in this scenario is a passive one, typical of contemporary women prophets who regarded themselves as a mere 'Instrument' of the Word. ${ }^{44}$ Her ministry was to

39 Baptised 1622? See 'Poole, Elizabeth (bap. 1622?, d. in or after 1668)', by Manfred Brod, in Oxford Dictionary of National Biography, http://www.oxforddnb.com/view/ article/47110; accessed Jan. 2013. The historiography of Poole's life and ministry is discussed by Larry Kreitzer, William Kiffen and his World (Part 2) (Oxford: Regents Park College, 2012), pp. 262-89.

${ }^{40}$ Charges she denied. Mack, Visionary Women, p. 98.

${ }^{41}$ See Larry J. Kreitzer, 'The Fifth Monarchist John Pendarves: Chaplain to Colonel Thomas Rainborowe's Regiment of Foot (1645-7)', Baptist Quarterly 43/2 (2009), pp. 112-22.

42 It is also suggested, by Ian Gentles, that Poole came into contact with the General Council via Colonel Nathaniel Rich, and David Underdown suggests Cromwell was the nexus. Lack of evidence makes the question indeterminable. See Marcus Nevitt, 'Elizabeth Poole Writes the Regicide', Women's Writing 9/2 (2002), p. 235.

43 Elizabeth Poole, An Alarum of War, Given to the Army (London, 1649), p. 1.

${ }^{44}$ Nevitt, 'Elizabeth Poole Writes the Regicide', p. 236. 
proclaim the given message, the passive constructions in the text emphasising that she is merely a channel of divine instruction. Henry Ireton's response to Poole's performance is illuminating, since he commented, 'I see nothing in her but those things that are the fruites of the spiritt of God.' 45 According to an anonymous pro-army pamphlet published a short time later, the ministry of Poole was well received:

Out of Hartfordshire unto the Generall Councell of the Army is come a woman of great wisedome and gravity, who told them she had a message to them from God, and desired they should heare her which they accordingly did with much acceptation; She saith they shall surely be prosperous, and attain their desires for a speedy settlement of the Kingdome, and that all powers shall be subdewed under their feet. ${ }^{46}$

Her second act of ministry, given to the Council on 5 January 1649 , was less well received. This time her message was delivered in the form of a document which counselled against the execution of the King, likening Charles to a husband of the people. On receiving the text the officers were anxious to question Poole about her words:

Col. Deane: I must desire to ask one question: whether you were commanded by the spiritt of God to deliver itt unto us in this manner.

Woman: I believe I had a command from God for itt.

Col. Deane: To deliver this paper in this forme?

Woman: To deliver in this paper or otherwise a message.

Col. Deane: And so you bringe itt, and present itt to us, as directed by his spirit in you, and commanded to deliver itt to us?

Woman: Yea Sir, I doe.

...

Mr Sadler: doe [you] offer this paper or [is it] from the Revelation of God? Woman: I saw noe vision, nor noe Angell, nor heard no voice, butt my spirit being drawne out about those thinges, I was in itt. Soe far as it is from God I thinke itt is a revelation. ${ }^{47}$

The remarkable feature about this exchange is that Poole was functioning as prophet in the public square, more particularly, the political sphere. Her words were not spoken in a church, but in Parliament, because in the congregation she was subject to the command to silence. Furthermore,

45 C. H. Firth, The Clarke Papers, vol. 2 (London: The Historical Society, 1992), p. 154.

46 The manner of the deposition of Charles Stewart, King of England, by the Parliament, and the Generall Councell of the Armie (London, 1649), p. 6.

47 Firth, The Clarke Papers, vol. 2, pp. 164-5, 167-8. 
having delivered her anti-regicide message as God's direction for the army, ${ }^{48}$ she experienced the prophet's fate, namely, rejection without honour. Poole's message was not what the army wanted to hear, and her words were disregarded and the King executed shortly after. Elizabeth Poole retired to Abingdon, where her gifts as a prophet were defended by Thomasine Pendarves, who wrote:

I have heard many professors and professions, but to my knowledge I never heard one come so near the power, I do not speak this as being affected with any person, party, or opinion. ${ }^{49}$

These are brief accounts of two women among the Particular Baptists who evidently displayed gifts of ministry and in both cases exercised that ministry beyond the bounds of the visible church. This pattern can be replicated in the cases of other Particular Baptist women who are known to have exercised a prophetic role, but were given no opportunity in the church. Anna Trapnel uttered a stream of visions and oracles in a twelve-day period during 1654 at Whitehall, during the trial of Vavasour Powell. ${ }^{50}$ Jane Turner, connected to the church of John Spilsbury, ${ }^{51}$ channelled her ministry through the written word, as she expounded her experience of grace in her conversion narrative. ${ }^{52}$ Likewise Katherine Sutton ${ }^{53}$ was described by her pastor, Hanserd Knollys as a 'Handmaide' of the Lord, and a Teacher, and a 'grave and Holy Matron', who was taught of God. ${ }^{54}$ She was, according to Knollys' testimony, 'not only Governesse, but (as it were) a Prophetess in her family', 55 on account of her diligence in leading family prayers and expounding the scriptures to her children and servants. ${ }^{56}$ Of her speaking Knollys testified, 'She opened her mouth with wisdom, and in her tongue was the Law of kindness', but her spoken ministry was confined to the domestic setting of the home: 'She

${ }^{48}$ See Poole, An Alarum of War, pp. 3-4.

${ }^{49}$ Ibid., p. 9. For the remainder of Elizabeth Poole's career see Kreitzer, William Kiffen, pp. 282-9.

50 A Company of Women Preachers, pp. 21-8.

51 In his preface to her work Choice Experiences, Spilsbery [sic] described Jane Turner as 'a Daughter of Zion', and 'a Mother in Israel'. See To the Christian Reader, p. i.

52 J. Turner, Choice Experiences of the Kind Dealings of God before, in, and after Conversion (London, 1653).

53 'Sutton, Katherine (fl. 1630-1663)', by Michael Davies, in Oxford Dictionary of National Biography, http://www.oxforddnb.com/view/article/69336; accessed Jan. 2013.

54 Katherine Sutton, A Christian Womans Experiences of the Glorious working of Gods free grace (London: Henry Goddaeus, 1663), pp. i-ii.

${ }^{55}$ Ibid., p. ii.

56 Anne Laurence discusses the role of the woman as source of religious guidance in the household. See 'A Priesthood of She-Believers', p. 346. 
did so Chatechise the young children, and instruct the elder maidens, that they all learned to know, and many of them to do their duty to God and man. 57

On what grounds did women preachers justify their ministry? Mrs Attaway, a General Baptist preaching woman, pointed to Acts 2:28, with its promise that God's Spirit would be poured out on all humankind and that 'your sons and daughters will prophesy', as justification for her ministry. ${ }^{58}$ Hanserd Knollys made reference to this text, but in its Old Testament form, Joel $2: 28-9,31-2$, in his commendation of the prophetic ministry of Katherine Sutton, which he recognised as a spiritual gift. ${ }^{59}$ If the Age of the Church was the Age of the Spirit, and if God had fulfilled his promise to bestow the Spirit on all people, then despite the Pauline prohibition in the Corinthian correspondence, who could forbid women from speaking?

In the 1641 tract, $A$ Discovery of Six Women Preachers, ${ }^{60}$ one of the women, Anne Hempstall, described her 'call' to preaching as the result of a dream in which she saw Anna, the biblical prophet mentioned in Luke 1:

the splendour of whose countenance did cast me into a trance, wherein I lay until the next morning, and the morning being come, I could conceive no interpretation of my Dream but this, that I should imitate godly Anna, by preaching unto you, as she prophesied to others. ${ }^{61}$

Another anonymous writer accused women preachers in sectarian congregations of having no other motive than to display their 'vanity, weaknesse, ignorance, pride, ambition, and vainglorie', and a desire to fulfil their 'unlawfull secret desires'. The pamphleteer continues:

Divers of them have lately advanced themselves with vain-glorious arrogance, to preach in mixt Congregations of men and women, in an insolent way, so usurping authority over men, and assuming a calling unwarranted by the word of God for women to use. ${ }^{62}$

57 In Sutton, A Christian Womans Experiences, p. ii.

58 See Thomas Edwards, Gangraena i.ii.30.

59 In Sutton, A Christian Womans Experiences, p. i.

60 Published anonymously.

61 A Discovery of Six Women Preachers, p. 2. Anne Hempstall is commonly described a Baptist, but while this is possible, there is no specific evidence for the identification. Baptist historians E. C. Starr and W. T. Whitley listed this document in their bibliographies among Baptist writings. For a summary of the evidence see Pamela Durso, 'Baptists and the Turn toward Baptist Women in Ministry', in M. E. Williams and W. B. Shurden, Turning Points in Baptist History (Macon, GA: Mercer University Press, 2008), p. 275 n.

62 A Spirit Moving in the Women-Preachers (London: Henry Shepheard, 1646), p. 3. Thomason corrects the date to 1645 . 
One testimony, being that of a woman preacher seeking to explain her inner conviction, and the other the perspective of a male critic observer, demonstrates the gulf in perceptions of what was emerging in that era of religious turbulence. Some believed that the eschatological age was dawning in which the Spirit abolished gender distinctions by giving the gift of preaching to men and women alike, while others believed the Prince of Darkness was stalking the land. William Prynne, the erastian lawyer, accused Baptists of permitting women to preach as bait to draw greater number of females into their sect. ${ }^{63}$

Prophetic women amongst the early Calvinistic Baptists highlighted a paradox, verging on a contradiction in their emerging ecclesiology. Baptists, on one hand, spoke of egalitarianism in ministry, which was no longer the preserve of clergymen authorised to officiate on the basis of ordination and apostolic authorisation. Ministry was the gift of King Jesus to his people, by the gifts of the Spirit. Since the Spirit blows where he will, any saint, potentially, might be a channel of spiritual grace and nourishment to other believers. This realisation of the theology of the 'Priesthood of Believers' was an experience of liberation and empowerment for many ordinary saints in Baptist churches. ${ }^{64}$ The one section of the community, however, which was excluded from this eschatological event was women. ${ }^{65}$ Ann Laurence poses these questions to the early Baptists:

If you believe in the primacy of the gathered congregation and in the ministry called by the congregation on the basis of the individual's gifts rather than his learning, what objection is there to women playing the same part as men?

63 William Prynne, A Fresh Discovery of Some Prodigious New Wandring-Blazing-Stars, \& Firebrands, Stiling Themselves New-Lights (London: John Macock, 1645), Epistle Dedicatory A2.

${ }^{64}$ Although often associated with Martin Luther, the phrase 'Priesthood of Believers' was never used by him; he spoke rather of the universal priesthood of believers. See Timothy J. Wengert, 'The Priesthood of All Believers and Other Pious Myths', Institute of Liturgical Studies Occasional Papers, Valparaiso University; http://scholar.valpo.edu/ils_papers/117/; accessed July 2016.

65 The only exception to this position I am aware of is the Seventh-Day Baptist Church of Dr Peter Chamberlen who decided, 'a Weoman, (Mayd, Wife or Widdow) being a Prophetess (1 Cor. 11) may speake, Prophesie, Pray, with a Vayl. Others may not.' In Claire Cross, 'The Church in England 1646-1660', in G. E. Aylmer (ed.), The Interregnum: The Quest for Settlement 1646-1660 (London: Macmillan, 1974), pp. 11617, spelling adjusted to original mss from Laurence, 'A Priesthood of She-Believers', p. 351. 
If there existed no requirement for ordination other than being called by a congregation, and if there was no educational qualification, what objection was there to the ministry of women? ${ }^{66}$

It has been shown above that there were women among the early Calvinistic Baptists who had prophetic and teaching gifts, acknowledged and verified by their male counterparts, but their ministry, such as it was, was not received in the church, but confined to the private domestic world of the home. In so far as Baptists were considered to be among the radical sects, they were most conservative in respect of the part women might take in congregational worship. Scriptural literalism was used to maintain patriarchy in the congregation, so while it was acknowledged that the Spirit might 'poure forth upon his servants, and Handmaides', ${ }^{67}$ they also took the view that in the church meeting that the same Spirit had inspired the Apostle to command their silence.

${ }^{66}$ Laurence, 'A Priesthood of She-Believers', pp. 349 and 358, respectively.

${ }^{67}$ Hanserd Knollys in Katherine Sutton, A Christian Womans Experiences, p. i. 